\title{
Association of single nucleotide polymorphisms in the bovine leptin and leptin receptor genes with growth and ultrasound carcass traits in Nellore cattle
}

R.C.G. da Silva ${ }^{1}$, J.B.S. Ferraz ${ }^{2}$, F.V. Meirelles $^{2}$, J.P. Eler ${ }^{2}$, J.C.C. Balieiro ${ }^{2}$, D.C. Cucco ${ }^{3}$, E.C. Mattos ${ }^{2}$, F.M. Rezende ${ }^{4}$ and S.L. Silva ${ }^{2}$

\author{
${ }^{1}$ Merial Saúde Animal Ltda., Campinas, SP, Brasil \\ ${ }^{2}$ Grupo de Melhoramento Animal e Biotecnologia, \\ Departamento de Ciências Básicas, \\ Faculdade de Zootecnia e Engenharia de Alimentos, \\ Universidade de São Paulo, Pirassununga, SP, Brasil \\ ${ }^{3}$ Universidade do Estado de Santa Catarina, Chapecó, SC, Brasil \\ ${ }^{4}$ Instituto de Genética e Bioquímica, Universidade Federal de Uberlândia, \\ Campus Avançado, Patos de Minas, MG, Brasil
}

Corresponding author: J.B.S. Ferraz

E-mail: jbferraz@usp.br

Genet. Mol. Res. 11 (4): 3721-3728 (2012)

Received November 3, 2011

Accepted March 13, 2012

Published August 17, 2012

DOI http://dx.doi.org/10.4238/2012.August.17.10

\begin{abstract}
Given the important role of leptin in metabolism, we looked for a possible association of leptin and leptin receptor polymorphisms with carcass and growth traits in Nellore cattle. We examined associations of leptin and leptin receptor SNPs with ultrasound carcass (longissimus dorsi muscle area (ribeye area), backfat thickness and rump fat thickness and growth traits (weaning weight adjusted to 210 days of age, yearling weight adjusted to 550 days of age, weight gain of weaning to yearling and scrotal circumference adjusted to 550 days of age) of 2162 Bos primigenius indicus (Nellore) animals. Allele and genotypic frequencies were calculated for each marker. Allele substitution, additive and dominance effects of the
\end{abstract}


polymorphisms were also evaluated. Some alleles of the molecular markers had low frequencies, lower than $1 \%$, in the sample analyzed, although the same polymorphisms described for B. p. taurus cattle were found. Due to very low allelic frequencies, the E2JW, A59V and UASMS2 markers were not included in the analysis, because they were almost fixed. E2FB was found to be significantly associated with weight gain, ribeye area and backfat thickness. The promoter region markers, C963T and UASMS1, were also found to be significantly associated with ribeye area. T945M was significantly associated with weight gain. We conclude that the leptin and receptor gene markers would be useful for marker-assisted selection.

Key words: Beef cattle; Bos indicus; Leptin; Molecular markers; Ultrasound traits

\section{INTRODUCTION}

Leptin, a hormone produced predominantly by adipocytes, performs important roles in the control of body weight, fat deposition, feed intake, immune function, and reproduction (Houseknecht et al., 1998; Clarke and Henry, 1999; Mácajová et al., 2004). Since the discovery of the leptin gene by Zhang et al. (1994) and of the leptin receptor gene by Tartaglia (1997), many studies have been published on polymorphisms in both genes in several species. Associations of single nucleotide polymorphisms (SNPs) in the leptin and leptin receptor genes with economically relevant traits have been reported in cattle by several authors (Buchanan et al., 2002; Liefers et al., 2004; Nkrumah et al., 2004, 2005; Ferraz et al., 2009; Souza et al., 2010).

Weaning weight adjusted to 210 days of age (WW), yearling weight adjusted to 550 days of age (YW), weaning to yearling weight gain (WG), and yearling scrotal circumference adjusted to 550 days of age (SC) are growth traits usually introduced by breeding programs. Backfat thickness (BFAT), rump fat thickness (RFAT), and longissimus muscle area (ribeye area, REA) are correlated with carcass quality and edible meat yield in carcasses. Genetic markers can be a useful tool for estimating breeding values and selecting animals for growth and carcass traits and may enable the early initiation of the selection processes.

Several studies have been conducted on Bos primigenius taurus, but few studies have examined the association between SNPs in the leptin or leptin receptor gene and carcass or growth traits on B. p. indicus.

The present study aims to evaluate the frequencies and effects of leptin and leptin receptor polymorphisms on carcass and growth traits in Nellore cattle.

\section{MATERIAL AND METHODS}

\section{Population}

Phenotypic and genotypic information of 2162 young Nellore bulls was used in the present study. All animals were sired by bulls selected for production and reproduction 
traits and controlled under a selection program designed to produce commercial bulls. Animals were raised under pasture conditions until 18 months of age. From the 18 months to slaughter, the animals were fed in feedlots until harvest at 22 to 26 months. Ultrasound measurements of carcass were obtained for 1856 animals and growth traits of 2162 animals were assessed.

\section{Phenotypic traits}

The growth traits evaluated were WW, YW, WG, and SC. Data were obtained from the databank maintained by the Animal Breeding and Biotechnology Group (GMAB) of the University of São Paulo.

The following carcass traits were evaluated by ultrasound measurement: REA, BFAT, and RFAT. Data regarding these traits were obtained at $21 \pm 1.6$ months of age. REA and BFAT were measured on the longissimus dorsi muscle from cross-sectional scans obtained between the 12th and 13th ribs. Vegetable oil and acoustic coupler were used on the scanning area to guarantee acoustic contact between the linear probe and shape of the scanned area for assessing the REA and BFAT traits. RFAT scan was obtained at the gluteus medius and biceps femoris muscles located between the hooks and pin bones. Vegetable oil was used on the scanning area to guarantee acoustic contact between the linear probe and scanned area for assessing the RFAT trait. Real-time ultrasound images were collected using Piemedical Scanner 200 VET equipped with a linear probe of $17.8 \mathrm{~cm}$ and a $3.5-\mathrm{MHz}$ transducer. The images were stored and analyzed by appropriate softwares.

\section{Genotyping and molecular markers}

DNA was extracted from the blood samples collected using EDTA vacuum tubes and impregnated on FTA cards. DNA extraction was performed by the $\mathrm{NaCl}$ extraction and precipitation method described by Olerup and Zetterquist (1992).

Eight markers located in the leptin and leptin receptor genes were studied in this research. The markers E2FB and E2JW were located on exon 2 (Buchanan et al., 2002; Lagonigro et al., 2003); A59V, on exon 3 (Haegeman et al., 2000) of the leptin gene; C963T, A1457G, UASMS1, and UASMS2, in the promoter region (Liefers et al., 2005; Nkrumah et al., 2005) of the leptin gene, and T945M, in exon 20 (Liefers et al., 2004) of the leptin receptor gene. The leptin gene is located on BTA 4 and the leptin receptor gene is located on BTA 3.

The genotypes were determined by DNA mass spectrometry (Sequenom iPlex ${ }^{\mathrm{TM}}$ Mass Spec) performed at laboratories located in the USA and licensed by IGENITY ${ }^{\circledR}$ (Duluth, GA, USA), a Merial Ltd. subdivision, the company that owns the exploration license rights on the markers analyzed.

\section{Statistical analysis}

Allelic and genotypic frequencies for each marker were estimated by simple counting of the different alleles and genotypes using PROC ALLELE from SAS/Genetics, version 9.1.3. Markers' effects on growth and ultrasound carcass traits were evaluated using the mixed-model methodology in a sire model, with PROC MIXED of SAS (SAS Institute Inc., 2004): 


$$
Y_{i j k}=\mu+C_{i}+\beta_{1}\left(I_{i j k}-\bar{I}\right)+\beta_{2}\left(M_{i j k}-\bar{M}\right)+S_{j}+e_{i j k}
$$

(Equation 1)

where $Y_{i j k}$ is the phenotypic value of an animal; $\mu$, the general mean of the trait; $C_{i}$, the fixed effect contemporary group; $\beta_{1}$, the coefficient for the covariate age at exam $\left(I_{i j k}\right) ; \beta_{2}$, the regression coefficient for a given genetic marker $\left(M_{i j k}\right) ; S_{j}$, the coefficient associated with the random effect of the sire, and $e_{i j k}$ is the random effect of the residual. Allele substitution effect was estimated by the method suggested by Falconer and Mackay (1996), by using $\beta_{2}$. F-statistic was considered significant for allelic substitution effect if the nominal $P$ value was lower than 0.05 .

Additive effect $(\alpha)$ was estimated using the contrasts between genotypic values $(\Phi)$ of homozygous (Falconer and Mackay, 1996) as described in Equation 2.

$$
\alpha=\Phi_{\mathrm{ii}}-\Phi_{\mathrm{jj}}
$$

Dominance effect $(\delta)$ was estimated using the contrasts between genotypic values $(\Phi)$ of heterozygous and the average of the genotypic values of homozygous (Falconer and Mackay, 1996), as described in Equation 3.

$$
\delta=\Phi_{\mathrm{ij}}-\left(\Phi_{\mathrm{ii}}+\Phi_{\mathrm{jj}} / 2\right)
$$

(Equation 3)

The contrasts were tested by the F-test using the SAS software.

\section{RESULTS AND DISCUSSION}

\section{Descriptive analysis and allelic and genotypic frequencies}

Descriptive statistics of growth and carcass traits are presented in Table 1. The phenotypic values of growth traits described in several publications evaluating Nellore cattle are in the range of 151.8-190.8 kg for WW; 274.7-347.1 kg for YW; 100.9-161.3 kg for WG, and 26.5-28.3 cm for SC (Martins et al., 2000; Pereira et al., 2000; Eler et al, 2006; Souza et al., 2010; Yokoo et al., 2010; Pedrosa et al., 2010; Van Melis et al., 2010; Faria et al., 2011; Laureano et al., 2011). The phenotypic values of ultrasound carcass traits described in several publications evaluating Nellore cattle are 45.1-65.0 $\mathrm{cm}^{2}$ for REA; 1.29-3.4 mm for BFAT, and 3.05$3.70 \mathrm{~mm}$ for RFAT (Prado et al., 2004; Silva et al., 2004; Souza et al., 2010; Yokoo et al., 2010). The mean values of YW, WG, SC, REA, and BFAT are within the range reported in several papers published evaluating Nellore animals with ages similar to those of our cattle. The mean values for WW and RFAT are slightly higher than the range reported in previous papers, but the standard deviation and coefficient of variation in our study are very similar to published data.

Allelic and genotypic frequencies are presented in Table 2. All leptin markers were polymorphic in Nellore cattle; therefore, the minor allele frequencies of E2JW, A59V, and UASMS 2 were very low $(<0.01)$. Consequently, very low allelic and genotype frequencies are always a problem in estimating additive effects because the mean value of the rare genotype might have been under- or overestimated (Ferraz et al., 2009). The markers E2JW, A59V, and UASMS2 had very low allelic frequencies, and they were not analyzed because they were almost fixed.

A few studies have described leptin and leptin receptor gene polymorphisms in Zebu breeds, mainly, in the Nellore breed. Choudhary et al. (2005) studied the allelic and genotypic frequencies of E2FB marker and reported the fixation of the C allele in Hariana, Sahiwal, Gyr, 
Table 1. Descriptive analysis for growth and carcass traits.

\begin{tabular}{lcrrrrr}
\hline Trait & $\mathrm{N}$ & Mean & SD & CV & Minimum & Maximum \\
\hline WW $(\mathrm{kg})$ & 2162 & 196.04 & 27.48 & 14.02 & 89.00 & 294.00 \\
YW $(\mathrm{kg})$ & 2154 & 322.20 & 47.08 & 14.61 & 162.00 & 510.00 \\
WG $(\mathrm{kg})$ & 2151 & 126.77 & 32.54 & 25.67 & 25.90 & 338.70 \\
SC $(\mathrm{cm})$ & 2143 & 27.50 & 3.25 & 11.80 & 17.00 & 38.00 \\
REA $\left(\mathrm{cm}^{2}\right)$ & 1856 & 65.09 & 7.42 & 11.40 & 40.20 & 73.80 \\
BFAT $(\mathrm{mm})$ & 1856 & 2.17 & 1.27 & 58.75 & 0.00 & 7.60 \\
RFAT $(\mathrm{mm})$ & 1856 & 3.82 & 1.86 & 48.75 & 0.00 & 11.90 \\
\hline
\end{tabular}

$\mathrm{N}=$ sample size; $\mathrm{SD}=$ standard deviation; $\mathrm{CV}=$ coefficient of variance; $\mathrm{WW}=$ weaning weight adjusted to 210 days of age; $\mathrm{YW}=$ yearling weight adjusted to 550 days of age; $\mathrm{WG}=$ weaning to yearling weight gain; $\mathrm{SC}=$ yearling scrotal circumference adjusted to 550 days of age; REA = ribeye area; BFAT = backfat thickness; RFAT = rump fat thickness.

\begin{tabular}{|c|c|c|c|c|c|}
\hline \multirow{2}{*}{$\frac{\text { Marker }}{\text { E2FB }}$} & \multicolumn{2}{|c|}{ Allele frequencies } & \multicolumn{3}{|c|}{ Genotypic frequencies (\%) } \\
\hline & $C-0.936$ & $\mathrm{~T}-0.064$ & $\mathrm{CC}=87.6$ & $\mathrm{CT}=11.9$ & $\mathrm{TT}=0.5$ \\
\hline E2JW & A - 0.999 & $\mathrm{~T}-0.001$ & $\mathrm{AA}=99.8$ & $\mathrm{AT}=0.2$ & $\mathrm{TT}=0$ \\
\hline A59V & $C-0.999$ & $\mathrm{~T}-0.001$ & $\mathrm{CC}=99.8$ & $\mathrm{CT}=0.2$ & $\mathrm{TT}=0$ \\
\hline C963T & C -0.979 & $\mathrm{~T}-0.021$ & $\mathrm{CC}=96.0$ & $\mathrm{CT}=3.8$ & $\mathrm{TT}=0.2$ \\
\hline A1457G & A -0.772 & $G-0.228$ & $\mathrm{AA}=60.2$ & $\mathrm{AG}=34.0$ & $\mathrm{GG}=5.8$ \\
\hline UASMS1 & $\mathrm{T}-0.978$ & C -0.022 & $\mathrm{TT}=95.8$ & $\mathrm{CT}=4.1$ & $\mathrm{CC}=0.1$ \\
\hline UASMS2 & $C-0.997$ & $\mathrm{~T}-0.003$ & $\mathrm{CC}=99.5$ & $\mathrm{CT}=0.5$ & $\mathrm{TT}=0$ \\
\hline T945M & $C-0.880$ & $\mathrm{~T}-0.120$ & $\mathrm{CC}=77.3$ & $\mathrm{CT}=21.3$ & $\mathrm{TT}=1.4$ \\
\hline
\end{tabular}

and Nimari breeds (Bos indicus). The authors suggested that this mutation occurred after the divergence of taurine and indicine cattle on the basis of the fact that it was only detected in taurine cattle. A recent study in Brazilian Nellore cattle of E2FB marker reported frequencies of 0.88 for allele $\mathrm{C}$ and 0.12 for allele $\mathrm{T}$ (Souza et al., 2010), which are close to data reported in this study. E2FB marker was polymorphic in Brazilian Nellore cattle diverging from the hypothesis of Choudhary et al. (2005); this is probably due to the participation of Bos taurus dams in the formation of this breed in Brazil, as reported by Meirelles et al. (1999).

This is the first study describing and studying the association of carcass traits with polymorphisms in the promoter region of the leptin gene in Nellore cattle. The promoter region regulates the transcription of DNA to mRNA, and it is very important to gene expression (Nelson and Cox, 2005). The markers C963T and A1457G were identified in Holstein cows by Liefers et al. (2005), who reported that the frequency of the $\mathrm{G}$ allele was 0.46 for $\mathrm{A} 1457 \mathrm{G}$ and that of the T allele was 0.33 for $\mathrm{C} 963 \mathrm{~T}$ in Holstein cows. In our study, these allele frequencies were lower than those reported by Liefers et al. (2005). The UASMS1 marker was identified by Nkrumah et al. (2005) in hybrid cattle in an experimental population and in different lines of a commercial population, and the reported frequencies of allele $\mathrm{C}$ in this population ranged from 0.41 to 0.62 . The frequency of the allele $\mathrm{C}$ for the UASMS1 marker was lower in Nellore cattle than those reported by Nkrumah et al. (2005).

T945M is located on the leptin receptor gene and was described in Holstein cows by Liefers et al. (2004), who reported that the frequency of the allele T was 0.04 . The frequency of the allele T in Nellore cattle was 3 times higher than that in Holstein cows.

Markers, for which minor allele frequencies are higher than 0.05 , can be used to estimate additive, dominance, and allelic substitution effects with more accuracy than others. 
The markers E2FB, A1457G, and T945M had minor allele frequency values higher than 0.05 .

\section{Association analysis}

E2JW, A59V, and UASMS2 markers were not analyzed due to very low minor allele frequency. Liefers et al. (2005) reported an association of A1457G with prepartum leptin concentrations but not during lactation in Holstein cows. However, in the present study, A1457G was not found to be associated with any trait in Nellore cattle.

E2FB is a mutation that occurs in exon 2 of the leptin gene and results in an amino acid substitution of arginine to cysteine in the leptin protein (Buchanan et al., 2002). The authors also reported that the allele T was associated with fatter carcasses in Angus, Charolais, Hereford, and Simmental bulls. Nkrumah et al. (2004) reported an association of the allele T of E2FB marker with improvement in fat thickness, daily gain, and backfat carcass score and of the allele $\mathrm{C}$ with improvement in yield grade and lean-meat yield in taurine cattle. Previous studies in Nellore cattle demonstrated that this marker was associated with birth weight and backfat thickness when analyzed by ANOVA, but no significant additive or dominance effects were found (Souza et al., 2010). Another study in Nellore cattle reported that E2FB was a good marker for the selection process to reduce drip-loss in Nellore cattle, an important trait for meat quality (Pinto et al., 2011). In the present study, E2FB was significantly associated with WG, REA, and RFAT traits. The allele $T$ was found to be significantly associated with increase in $W G(P=0.0457)$ and RFAT $(\mathrm{P}=0.0356)$ on allele substitution analysis; however, an additive effect was significantly noted for WG and a dominance effect, for RFAT. The allele $\mathrm{C}$ was significantly associated with an increase in REA $(\mathrm{P}=0.0256)$ and exhibited a dominance effect in this trait (Table 3). E2FB was significantly associated with 3 economically important traits, probably due to a pleiotropic effect of this polymorphism. Further studies must be conducted to verify this hypothesis.

\begin{tabular}{|c|c|c|c|c|c|}
\hline Marker & Trait & Favorable allele & $\beta_{1} \pm \mathrm{SE} \mathrm{P}$ value & Dominance effect $P$ value & Additive effect $\mathrm{P}$ value \\
\hline \multirow[t]{3}{*}{ E2FB } & WG & $\mathrm{T}$ & $\begin{array}{c}2.71 \pm 1.35 \\
0.0457\end{array}$ & 0.0952 & 0.0291 \\
\hline & REA & C & $\begin{array}{c}1.05 \pm 0.47 \\
0.0256\end{array}$ & 0.0215 & 0.9053 \\
\hline & RFAT & $\mathrm{T}$ & $\begin{array}{c}0.28 \pm 0.13 \\
0.0356\end{array}$ & 0.0328 & 0.8791 \\
\hline C963T & REA & $\mathrm{T}$ & $\begin{array}{c}2.08 \pm 1.04 \\
0.0451\end{array}$ & 0.0451 & 0.1207 \\
\hline UASMS1 & REA & $\mathrm{C}$ & $\begin{array}{c}2.35 \pm 0.99 \\
0.0176\end{array}$ & 0.0176 & 0.1562 \\
\hline T945M & WG & $\mathrm{T}$ & $\begin{array}{c}3.22 \pm 1.16 \\
0.0084\end{array}$ & 0.1052 & 0.0084 \\
\hline
\end{tabular}

$\mathrm{WG}=$ weight gain; REA $=$ ribeye area; RFAT $=$ rump fat thickness.

C963T and UASMS1 are located in the promoter region of leptin gene. C963T was associated with leptin concentrations in Holstein cows; the allele $\mathrm{T}$ was favorable in increasing the leptin concentrations, and allele $\mathrm{C}$ was favorable for increasing the dry matter intake and decreasing the days to first postpartum ovulation (Liefers et al., 2005). No other study on the association of this marker with economically important traits was found. The C963T is a mutation that causes a substitution of $\mathrm{C}$ to $\mathrm{T}$, which was found to be associated with REA in this study. The allele $\mathrm{T}$ was 
responsible for increasing REA and was more dominant than allele C. The UASMS1 marker was associated with final body weight, dry mater intake, and BFAT of taurine cattle in a study reported by Nkrumah et al. (2005). Another study on bulls of taurine breeds demonstrated an association of this marker with fat thickness on carcass (Schenkel et al., 2005). These markers were associated with REA. The UASMS1 marker is a mutation in promoter region of leptin gene that causes a substitution of $\mathrm{C}$ to $\mathrm{T}$, which in the present study, was associated with REA. The allele $\mathrm{C}$ was responsible for increasing REA and dominant when compared with allele T. No study in taurine breeds reported an association of promoter-region polymorphisms with REA. Both markers were significantly associated with REA, but allele substitution and dominance effects and allele and genotypic frequencies were very similar (Table 3). Therefore, additional studies of linkage disequilibrium with these markers must be performed before using them in marker-assisted selection.

T945M is a marker located on leptin receptor gene on BTA 3 and involves a substitution of $\mathrm{T}$ to $\mathrm{C}$. The allele $\mathrm{T}$ was associated with increase of higher plasmatic leptin concentrations in Holstein cows (Liefers et al., 2004). In a previous study in Nellore cattle, this marker was significantly associated with REA and BFAT of carcass after slaughter (Ferraz et al., 2009). In the present study, no association of T945M with BFAT or RFAT was found when the traits were evaluated using ultrasound measurements. A highly significant association of T945M with WG $(\mathrm{P}<0.01)$ and an additive effect for WG were also noted. These results demonstrated that this marker can be a good candidate for inclusion in marker-assisted selection programs.

\section{CONCLUSION}

All markers were polymorphic in the Nellore animals, but the E2JW, A59V, and UASMS2 markers had very low minor allele frequencies and were not analyzed because these markers were almost fixed. E2FB was significantly associated with WG, REA, and BFAT, and can therefore be considered a good candidate for inclusion during marker-assisted selection. The promoter region markers C963T and UASMS1 were significantly associated with REA, but additional studies are necessary to evaluate the Mendelian inheritance of these markers. T945M had a highly significant association with WG and can be considered a good marker for marker-assisted selection.

Leptin has an important role in metabolism and a study of the effects of the polymorphisms in the leptin and leptin receptor genes can direct the method of use and the importance of using these genes in marker-assisted selection. Although the finding of this study suggest an association between these genes and certain traits, additional studies are necessary to explain the underlying biological mechanism and relationship of these polymorphisms with phenotypes in Nellore cattle.

\section{ACKNOWLEDGMENTS}

The authors thank FUNPEC/RP for master scholarship and financial support, Merial Saúde Animal/Igenity for genotyping animals and Agro-Pecuária CFM Ltda. for the phenotype collection.

\section{REFERENCES}

\footnotetext{
Buchanan FC, Fitzsimmons CJ, Van Kessel AG, Thue TD, et al. (2002). Association of a missense mutation in the bovine leptin gene with carcass fat content and leptin mRNA levels. Genet. Sel. Evol. 34: 105-116.

Choudhary V, Kumar P, Bhattacharya TK, Bhushan B, et al. (2005). DNA polymorphism of leptin gene in Bos indicus and Bos taurus cattle. Genet. Mol. Biol. 28: 740-742.
} 
Clarke IJ and Henry BA (1999). Leptin and reproduction. Rev. Reprod. 4: 48-55.

Eler JP, Ferraz JB, Balieiro JC, Mattos EC, et al. (2006). Genetic correlation between heifer pregnancy and scrotal circumference measured at 15 and 18 months of age in Nellore cattle. Genet. Mol. Res. 5: 569-580.

Falconer DS and Mackay TFC (1996). Introduction to Quantitative Genetics. 4th edn. Longman, London.

Faria CU, Terra JP, Yokoo MJ, Magnabosco CU, et al. (2011). Interação genótipo-ambiente na análise genética do peso ao desmame de bovinos Nelore sob enfoque bayesiano. Acta. Sci. Anim. Sci. 33: 213-218.

Ferraz JB, Pinto LF, Meirelles FV, Eler JP, et al. (2009). Association of single nucleotide polymorphisms with carcass traits in Nellore cattle. Genet. Mol. Res. 8: 1360-1366.

Haegeman A, Van ZA and Peelman LJ (2000). New mutation in exon 2 of the bovine leptin gene. Anim. Genet. 31: 79.

Houseknecht KL, Baile CA, Matteri RL and Spurlock ME (1998). The biology of leptin: a review. J. Anim. Sci. 76: 1405-1420.

Lagonigro R, Wiener P, Pilla F, Woolliams JA, et al. (2003). A new mutation in the coding region of the bovine leptin gene associated with feed intake. Anim. Genet. 34: 371-374.

Laureano MMM, Boligon AA, Costa RB, Forni S, et al. (2011). Estimates of heritability and genetic trends for growth and reproduction traits in Nelore cattle. Arq. Bras. Med. Vet. Zootec. 66: 143-152.

Liefers SC, Veerkamp RF, te Pas MF, Delavaud C, et al. (2004). A missense mutation in the bovine leptin receptor gene is associated with leptin concentrations during late pregnancy. Anim. Genet. 35: 138-141.

Liefers SC, Veerkamp RF, te Pas MF, Delavaud C, et al. (2005). Leptin promoter mutations affect leptin levels and performance traits in dairy cows. Anim. Genet. 36: 111-118.

Mácajová M, Lamosova D and Zeman M (2004). Role of leptin in farm animals: a review. J. Vet. Med. A Physiol. Pathol. Clin. Med. 51: 157-166.

Martins GA, Martins Filho R, Lima FAM and Lôbo RNB (2000). Influence of genetic and environment factors on the growing traits of animals from Nellore breed at Maranhão State. R. Bras. Zootec. Zootec. 29: 103-107.

Meirelles FV, Rosa AJM, Lôbo RB, Garcia JM, et al. (1999). Is the american Zebu really Bos indicus? Genet. Mol. Biol. 22: 543-546.

Nelson DL and Cox MM (2005). Lehningher Principles of Biochemistry. 6th edn. Prentice Hall, New York.

Nkrumah JD, Li C, Basarab JB, Guercio S, et al. (2004). Association of a single nucleotide polymorphism in the bovine leptin gene with feed intake, feed efficiency, growth, feeding behaviour, carcass quality and body composition. Can. J. Anim. Sci. 84: 211-219.

Nkrumah JD, Li C, Yu J, Hansen C, et al. (2005). Polymorphisms in the bovine leptin promoter associated with serum leptin concentration, growth, feed intake, feeding behavior, and measures of carcass merit. J. Anim. Sci. 83: 20-28.

Olerup O and Zetterquist H (1992). HLA-DR typing by PCR amplification with sequence-specific primers (PCR-SSP) in 2 hours: an alternative to serological DR typing in clinical practive including donor-recipient matching in cadaveric transplantation. Tissue Antigens 39: 225-235

Pedrosa VB, Eler JP, Ferraz JB, Silva JAV, et al. (2010). Parâmetros genéticos do peso adulto e características de desenvolvimento ponderal na raça Nelore. Rev. Bras. Saúde Prod. An. 11: 104-113.

Pereira E, Eler JP and Ferraz JBS (2000). Genetic correlation between scrotal circumference and some reproductive traits in Nellore cattle. Rev. Bras. Zootec. 29: 1676-1683.

Pinto LF, Ferraz JB, Pedrosa VB, Eler JP, et al. (2011). Single nucleotide polymorphisms in CAPN and leptin genes associated with meat color and tenderness in Nellore cattle. Genet. Mol. Res. 10: 2057-2064.

Prado CS, Padua JT, Corrêa MPC, Ferraz JBS et al. (2004). Comparação de diferentes métodos de avaliação da área de olho de lombo e cobertura de gordura em bovinos de corte. Ciênc. Anim. Bras. 5: 141-149

SAS Institute Inc. (2004). SAS/STAT 9.1. User's Guide. SAS Publishing, Cary.

Schenkel FS, Miller SP, Ye X, Moore SS, et al. (2005). Association of single nucleotide polymorphisms in the leptin gene with carcass and meat quality traits of beef cattle. J. Anim. Sci. 83: 2009-2020.

Silva SL, Leme PR, Putrino SM, Martello LS, et al. (2004). Prediction of backfat at slaughter, by ultrasound, in Nellore and Brangus Young bulls. Rev. Bras. Zootec. 33: 511-517.

Souza FR, Mercadante ME, Fonseca LF, Ferreira LM, et al. (2010). Assessment of DGAT1 and LEP gene polymorphisms in three Nelore (Bos indicus) lines selected for growth and their relationship with growth and carcass traits. J. Anim. Sci. 88: 435-441.

Tartaglia LA (1997). The leptin receptor. J. Biol. Chem. 272: 6093-6096.

Van Melis MH, Oliveira HN, Eler JP, Ferraz JB, et al. (2010). Additive genetic relationship of longevity with fertility and production traits in Nellore cattle based on bivariate models. Genet. Mol. Res. 9: 176-187.

Yokoo MJ, Lobo RB, Araujo FR, Bezerra LA, et al. (2010). Genetic associations between carcass traits measured by realtime ultrasound and scrotal circumference and growth traits in Nelore cattle. J. Anim. Sci. 88: 52-58.

Zhang Y, Proenca R, Maffei M, Barone M, et al. (1994). Positional cloning of the mouse obese gene and its human homologue. Nature 372: 425-432. 